\title{
MESTO ZAPADNOG BALKANA U AGENDAMA RUSIJE I TURSKE U KONTEKSTU HIBRIDNIH PRETNJI
}

\author{
Nebojša Nikolić ${ }^{*}$ \\ Univerziteta odbrane u Beogradu, Institut za strategijska istraživanja
}

radu se analizira širi kontekst odnosa Rusije i Turske u savremenom bezbednosnim uslovima koje karakteriše prisustvo hibridnih pretnji, sa ciljem da se sagleda mesto i značaj regiona Zapadnog Balkana u bezbednosnoj agendi ovih sila. Svrha analize jeste poboljšanje metodološkog pristupa za objektivniju percepciju aktivnosti i namera i pre svega relativnog značaja koji velike sile pridaju regionu Zapadnog Balkana u kontekstu ostalih oblasti i pitanja u kojima se sučeljavaju njihovi interesi. Izabrane su dve velike sile, Rusija i Turska, kao strani faktori koji su u dužem istorijskom periodu sa različitim intenzitetom bili prisutni u ovom regionu. $U$ cilju ostvarenja sopstvenih interesa i projektovanja uticaja strani faktori preduzimaju čitav niz različitih mera i aktivnosti koje su u savremenim analizama u oblasti odbrane i bezbednosti često imenovane kao hibridne pretnje, pa se na samom početku rada daje kratki osvrt na koncept hibridnog ratovanja kroz evaluaciju istaknutih pitanja i odgovora od praktičnog interesa za nosioce odlučivanja na strategijskom nivou.

Ključne reči: Zapadni Balkan, Srbija, hibridne pretnje, velike sile, metodologija procene, percepcija značaja, Rusija, Turska

\section{Uvod}

Dominantne percepcije u zemljama na Zapadnom Balkanu ponekad imaju sužen okvir posmatranja i razumevanja ponašanja velikih sila u ovom regionu, uz neargumentovano precenjivanje sopstvenog značaja i važnosti u planovima tih velikih sila, kao i unošenje emocionalnih elemenata u oblast međunarodnih odnosa gde se uglavnom vrednuju i mere samo interesi. Međusobni odnosi velikih sila su sami po sebi vrlo kompleksni, višeslojni ali i pragmatični pre svega. Velike sile se u nekim regionima ili po nekim pitanjima slažu, koordiniraju akcije i čak pomažu, dok u drugim oblastima ili pitanjima dolazi do razmimoilaženja i konfrontacije.

U sprovođenju svojih interesa, velike sile imaju na raspolaganju širok spektar mogućnosti i resursa. Različite forme savremenih konflikata često se prikazuju kao rezultat pro-

\footnotetext{
"Pukovnik dr Nebojša Nikolić je rukovodilac projekta: „Hibridno ratovanje - iskustva i perspektive“ Instituta za strategijska istraživanja, nebojsa.nikolic11@mod.gov.rs.
} 
jekcije hibridnih pretnji i imenuju kao hibridno ratovanje. Široka prisutnost i aktuelnost ${ }^{1}$ fenomena hibridnog ratovanja je razlog da na samom početku rada damo kratki osvrt na koncept hibridnog ratovanja kroz evaluaciju istaknutih pitanja i odgovora od praktičnog interesa za nosioce odlučivanja na strategijskom nivou.

U drugom i trećem poglavlju prikazani su rezultati nekoliko ekspertskih viđenja mesta i značaja regiona Zapadnog Balkana u strategijskim agendama dve izabrane velike sile Rusije i Turske. Svakako, i ostale velike sile pomno prate razvoj događaja na Zapadnom Balkanu i moguće trendove i scenarije ${ }^{2}$ razvoja situacije u budućnosti ${ }^{3}$ sa posebnim ${ }^{4}$ akcentom na Srbiju, ali u ovom radu se ograničavamo na pomenute dve velike sile. Međusobni odnosi Rusije i Turske postali su veoma aktuelni ${ }^{5}$ u novije vreme i predmet su mnogih istraživanja ${ }^{6}$. U četvrtom poglavlju sažeto je prikazan međusobni ${ }^{7}$ odnos ove dve velike sile, što je posebno interesantno u aktuelnom vremenskom trenutku u širem kontekstu i u sklopu odnosa ove dve zemlje sa drugim velikim silama, kao i sa aspekta tekućih konflikata ${ }^{8}$ na Bliskom Istoku i rastućih tenzija u Južnoj Americi.

\section{Kontekst hibridnih pretnji}

Kontekst savremenih hibridnih pretnji ovde se daje u najkraćem obimu i to na način struktuiran kroz moguće odgovore na nekoliko pitanja koja se logično nameću u kontekstu interesovanja donosilaca odluka u sistemu odbrane i bezbednosti ali i šireg kruga zainteresovanih. U praksi, donosioci odluka žele jednostavne i kratke odgovore na sledeće pitanja: šta je hibridni rat; ko je prepoznat kao nosilac hibridnog ratovanja; ko su moguće mete hibridnog ratovanja; koje se metode koriste u hibridnom ratovanju; koje snage sprovode hibridno ratovanje (HR) protiv druge strane; i konačno, kako se odbraniti od hibridnih pretnji i pobediti u hibridnom ratu? U nastavku sledi kratak osvrt na osnovna pitanja koja se nameću u kontekstu hibridnih pretnji bezbednosti i hibridnom ratovanju ali bez šire elaboracije, koja je svakako moguća i potrebna ali nije predmet ovog rada.

Definicija hibridnog ratovanja. Hibridno ratovanje ${ }^{9}$ je novi termin kojim se pokušavaju obuhvatiti i istaći sve specifičnosti savremenih sukoba u prve dve decenije dvadeset prvog veka. Opšteprihvaćene definicije hibridnog ratovanja još uvek nema i pored velike

\footnotetext{
${ }^{1}$ Tagarev, Todor, (2018). "Hybrid Warfare: Emerging Research Topics", Information \& Security: An International Journal Vol.39, 289-300.

${ }^{2}$ Graham Thomas, Levitsky Jonathan, Munter Cameron, Wisner Frank, "Time for Action in the Western Balkans", Policy report, May 2018, EastWest Institute

${ }^{3}$ Čeperković Marko, Gaub Florence, "Balkan Futures", Chaillot Papers, August 2018, European Union Institute for Security Studies, 2018.

${ }^{4}$ Hartwell, Chritopher, "Saradnja Srbije sa Kinom, Evropskom unijom, Rusijom i Sjedinjenim Americkim Drzavama", Studija Resornog odeljenja Glavne uprave za spoljnu politiku Evropski parlament, EU, 2017.

${ }^{5}$ Kortunov Andrey, Ersen Emre, "Deepening Turkey-Russia Relations", Perceptions, 2018, Vol. XXIII, No.2, pp.1-3.

${ }^{6}$ Alexandrova-Arbatova, Nadia, "The Russia-Turkey Relations: Startegic Partnership or Strategic Rivalry", Policy paper series 4/2018, December 2018, Cyprus Center for European and International Affairs, University of Nicosia, Cy

${ }^{7}$ Seyfettin, Mehmet, Erol, "Fundamental Dynamics and Russia Dimension of the New Turkish Foreign Policy Direction", report, Ankara Center for Crisis and Policy Studies, ANKASAM, 6 Jul, 2018

${ }^{8}$ Zulfqar Saman, "Competing Interest of Major Powers in the Middle East: The Case Study of Syria and Its Implications for Regional Stability", Perceptions, 2018, Vol. XXIII, No.1, pp.121-148.

${ }^{9}$ Milošević Davor, Pojmovno odredjenje fenomena "hibridnog ratovanja", Vojno delo 3/2018.
} 
popularnosti ovog termina u stručnim ${ }^{10}$ i naučnim krugovima. Inicijalno, pod hibridnim ratovanjem $^{11}$ se smatrala kombinovana primena konvencionalnih vojnih sposobnosti i specijalnih snaga ${ }^{12}$, neregularnih dejstava, teroristički akti i kriminalno delovanje. U kombinovanoj primeni različitih oblika očekuje se sinergetski efekat kako u fizičkom tako i u psihološkom $^{13}$ domenu konflikta. Kasnije, percepcija hibridnog ratovanja je proširena i na sve druge oblike, sredstva i načine ugrožavanja bezbednosti. Najprostije rečeno, u najširem smislu, hibridni rat je svako delovanje bilo kojim sredstvima na bilo koji način kojim se podriva-ometa-šteti neka-protivnička-suparnička-neprijateljska država, njena ekonomija, narod i celokupan društveni život. U užem smislu, hibridni rat je podrivanje državnog poretka u protivničkoj državi na bilo koji način i bilo kojim sredstvima.

Nosioci hibridnog ratovanja. Organi državne vlasti, organizacije i timovi iz sektora bezbednosti, sektora spoljne politike i sl.., kao i nedržavni akteri, su osnovni nosioci. Međutim, nosioci obično deluju preko izvršioca ili „proksi“ subjekata, odnosno posrednika (druge države, organizacije i pokreti; NVO; mediji, medijske ličnosti; banke, finansijske institucije; velike kompanije; privatne kompanije u oblasti bezbednosti; mafija i kriminalne grupe i pojedinci; sekte i slične organizacije (tzv. patriotske, omladinske, ekološke, filantropske, itd.).

Moguće mete hibridnog ratovania. Mete ${ }^{14}$ ili objekti hibridnog ratovanja mogu biti svi: države, međunarodne organizacije, svi državni organi, vojska, policija, agencije, rukovodioci i istaknuti pojedinci; objekti kritične infrastrukture; ekonomija, saobraćaj, proizvodni pogoni, skladišta opasnih i zapaljivih materija, vojna skladišta, sportska, kulturna i druga okupljanja, istorijski objekti, mediji i medijski prostor, bankarski sektor, društvene mreže itd. Osim ljudi i materijalnih objekata, mete mogu biti i apstraktne vrednosti (istorija, istorijske ličnosti i događaji; tradicija; običaji; sistem vrednosti, i sl., mogu biti izložene krađi, pogrešnom tumačenju, omalovažavanju i diskreditaciji, itd.). Koja meta će biti odabrana zavisi od cilja koji se želi, od raspoloživih sredstava i metoda, kao i od karakteristika i trenutnog stanja države koja je objekat hibridnog dejstva.

Metode u hibridnom ratovanju. Sve moguće metode ometanja, sprečavanja, opstrukcije, nanošenja štete, uslovljavanja, usporavanja, itd., odnosno:

- ekonomske ${ }^{15}$, finansijske, saobraćajno-transportne sankcije i blokade u cilju urušavanja privrede zemlje koja je objekat napada u hibridnom ratu;

- energetski rat $^{16}$ (uskraćivanje, uslovljavanje ili otežavanje snabdevanja energentima);

\footnotetext{
${ }^{10}$ Vračar Milinko, Milica Ćurčić, „The Evolution of European Perception of the Term Hybrid Warfare“, Vojno delo, 1/2018

${ }^{11}$ Nikolić Nebojša, (2017), "Razmatranje inovativnosti koncepta hibridnog ratovanja”, časopis Vojno delo, broj 5 , 2017, 320-332.

${ }^{12}$ Berić, Nenad, Jović, Nikola, Simić Nenad, (2018). „Uloga specijalnih snaga u hibridnom ratovanju“, Tematski zbornik radova: „Hibridno ratovanje - dilema koncepta savremenih sukoba“, Institut za strategijska istraživanja, Univerzitet odbrane, Beograd, 2018.

${ }^{13}$ Vučinić Dejan, Psihološko ratovanje u prostoru društvenih informacionih medija - aspekt hibridnog ratovanja, Vojno delo, 7/2017.

${ }^{14}$ Nikolic Nebojsa, (2018), "Connecting Conflict Concepts: Hybrid Warfare and Warden's Rings", Information \& Security: AnInternational Journal Vol.41: 21-34.

${ }^{15}$ Cvetković, Nenad, Kovač, Mitar, Mak, Antonio, (2018). „Ekonomski sadržaj hibridnog ratovanja“, Tematski zbornik radova: „Hibridno ratovanje - dilema koncepta savremenih sukoba“, Institut za strategijska istraživanja, Univerzitet odbrane, Beograd, 151-168.

${ }^{16}$ Mitrović Miroslav, Ekonomski i energetski aspekti hibridnog ugrožavanja nacionalne bezbednosti, Vojno delo, Beograd, 6/2017
} 
- medijski rat ${ }^{17}$ (distorzija informacija, asimetrično izveštavanje, zamena uloga uzroka i posledice, zamena uloga žrtve i krivca, diskreditacija, izolacija, lažne vesti i lažne informacije, upotreba društvenih mreža ${ }^{18}$ i drugi oblici informacionih operacija ${ }^{19}$ );

- podsticanje višestrukih podela između stanovništva zemlje - objekta napada (podele po etničkoj, verskoj ${ }^{20}$, političkoj, stranačkoj pripadnosti i drugim kriterijumima uz eksploataciju kulturnih ${ }^{21}$ i mentalitetskih matrica);

- otežavanje funkcionisanja državnih granica i prelaza (narušavanje graničnog režima, ilegalne migracije, nepotrebna zadržavanja građana, opstrukcija propusne moći graničnih prelaza, itd.);

- izolacija na međunarodnom nivou (lišavanje saveznika u cilju slabljenja pozicije);

- smanjenje nivoa diplomatskih, ekonomskih, vojnih, sportskih, medijskih ${ }^{22}$, i drugih odnosa);

- pritisci na rukovodstvo zemlje (u cilju smanjenja manevarskog prostora i kredibiliteta);

- podsticanje samourušavanja ${ }^{23}$ države (stimulisanjem korupcije, nepotizma, poltronizma, klijentelizma, tribalizma, kronizma, trgovine uticajem, negativnom selekcijom, progonom i izopštavanjem najsposobnijih, donošenje zakonskih propisa kojima se narušavaju elementarna prava građana, povećanja poreza i uvođenje novih, ukidanja socijalnih i drugih prava, itd.);

- skretanje pažnje sa bitnih događaja-pitanja-problema i nametanje manje bitnih (forsiranje neželjene agende rada, pregovaranja, delovanja itd.);

- vrbovanja, ucene, atentati ličnosti od uticaja i visokih zvaničnika;

- iniciranje nereda, narušavanje javnog reda i mira;

- nasilna promena ponašanja režima ${ }^{24}$ (ucene ili potkupljivanje najviših zvaničnika);

- nasilna promena režima ${ }^{25}$ (pučevi, „obojene revolucije“, impičment, atentat, građanski rat, strane intervencije);

- hakerisanje (neovlašćeni upad u tuđe računarske sisteme), kompjuterski kriminal, kompjuterski terorizam i drugi oblici dejstava u sajber ${ }^{26}$ prostoru;

- prisluškivanje i praćenje telekomunikacija;

\footnotetext{
${ }^{17}$ Mitrović Miroslav, Genesis of Propaganda as a Strategic Means of Hybrid Warfare Concept, Vojno delo, International Edition, 1/2018.

${ }^{18}$ Saković Radiša, Miroslav R. Terzić, Upotreba društvenih mreža u hibridnom ratovanju, Vojno delo 7/2018.

${ }^{19}$ Miljković, Milan, (2018). „Hibridno ratovanje u savremenim domenima . Primer informacionih operacija“, Tematski zbornik radova: „Hibridno ratovanje - dilema koncepta savremenih sukoba“, Institut za strategijska istraživanja, Univerzitet odbrane, Beograd, 169-180.

${ }^{20}$ Subotić Milovan, Miroslav Mitrović: „Hybrid Nature of Extremism: Cohesive Characteristics of Ethno-Nacionalism and Religious Extremism as Generators of Balkan Unsecurity", Vojno delo, International Edition, 1/2018.

${ }^{21}$ Vujčić, Igor, (2018). „Doprinos kulturne antropologije identifikaciji, prevenciji i razumevanju hibridnih pretnji u društvenoj i informacionoj sferi“, Tematski zbornik radova: „Hibridno ratovanje - dilema koncepta savremenih sukoba“, Institut za strategijska istraživanja, Univerzitet odbrane, Beograd, 183-194.

${ }^{22}$ Mitrović Miroslav, Javna diplomatija u paradigmi hibridnog koncepta sukoba, Vojno delo 2/2018.

${ }^{23}$ Nikolic Nebojsa, (2018), "Obstacles in Inter-Organizational Cooperation and Hybrid Threats", Information \& Security: An International Journal Vol.39: 29-41.

${ }^{24}$ Nikolic, Nebojsa. "Comparative Review of Hybrid Warfare and Special Warfare", Thematic Conference Proceedings of International Scientific Conference "Archibald Reiss Days 2017".

${ }^{25}$ Milenković Miloš, Nasilna promena režima kao sadržaj hibridnog rata, Vojno delo 6/2017.

${ }^{26}$ Vasiljević, Dragan, Vasiljević, Julijana, Đurić, Alaksandar, (2018). „Sajber prostor - Definicija i klasifikacija“, Tematski zbornik radova: „Hibridno ratovanje - dilema koncepta savremenih sukoba“, Institut za strategijska istraživanja, Univerzitet odbrane, Beograd, 214-227.
} 
- ekonomski rat ${ }^{27}$ (posredne i neposredne zabrane poslovanja, uslovljavanja);

- carinski rat;

- finansijski rat (blokade računa, zamrzavanje depozita, izazivanje inflacije);

- projektovanje-širenje svoje kulture ${ }^{28}$ i vere $^{29}$, itd.

Snage koje sprovode hibridno ratovanje (HR) protiv druge strane. Inicijatori i nosioci HR, ukoliko im već ne stoje na raspolaganju, biraju za izvršioce eksperte i timove odgovarajućeg stručnog ili socijalnog profila (mineri, programeri, sociolozi, psiholozi, biolozi, fizikohemičari, bankari, pravnici, popularne ličnosti (muzika, film, sport, ...), vođe navijačkih grupa, vođe kriminalnih grupa, kao i profesionalni državni-vojni-policijski oružani timovi za specijalno ratovanje, specijalne vojne jedinice i sredstva, koje angažuju na način, u vreme, i u pravcu za koji procene da će biti najefektniji. „Posrednost“ je veoma važan aspekt, odnosno nosioci najčešće teže da ostanu skriveni i da ne bude viđena-otkrivena njihova direktna veza sa neposrednim izvršiocima hibridnih oblika ugrožavanja bezbednosti. Na taj način nosioci izbegavaju direktnu odgovornost za iniciranje sukoba, a sa druge strane protivnik ostaje zbunjen jer ne zna ko i zašto ga napada što dodatno doprinosi efikasnosti i efektivnosti hibridnih akcija. Na primer, neki pučevi na našim prostorima ostali su nedovoljno razjašnjeni u pogledu naručioca (od atentata na kneza Mihaila u 19. veku do pučeva i atentata u 20. i 21. veku), a sami ti događaji imali su ogroman uticaj na demografsko, ekonomsko i drugo stradanje naroda i države. Problem važnosti i težine otkrivanja naručioca pučeva i eliminisanja vladara jasno je vidljiv i u poslednjem pokušaju puča u Turskoj 2016. godine (stotine hiljada ljudi je procesuirano, ali nema konkretnih dokaza o dominirajućim sumnjama u ovom slučaju).

Odbrana od hibridnih pretnji. Najbolja odbrana od hibridnih pretnji i poraza u hibridnom ratovanju jeste preventiva i umrežavanje ${ }^{30}$ kao i adekvatan razvoj ${ }^{31}$ svih odbrambenih kapaciteta. Jedna od osnovnih ideja u hibridnom ratovanju jeste orijentacija na iskorišćavanje slabih tačaka protivničke strane. Upravo zato je preventivno delovanje značajno ukoliko je isto dugoročno orijentisano na eliminaciju slabih tačaka jednog društva, države ili organizacije. Kao glavni nosilac odbrane od hibridnih pretnji prepoznat je sistem odbrane, odnosno vojska države. To dalje implicira obavezu provođenja adekvatnih priprema i osposobljavanja, kao i umrežavanja ostalih subjekata države i nacionalnih potencijala za odbranu zemlje. Centralnu ulogu u tome ima vojni oficirski kadar od koga se najviše očekuje. Dalje, glavni oblici pripreme oficira za odbranu zemlje od hibridnog ugrožavanja jesu obuka i obrazovanje ${ }^{32}$, pri čemu obrazovanje ima poseban značaj s obzirom na dugoročnost, višeslojnost i složenost obrazovnog procesa koji na nivou visokog vojnog obrazovanja ima i dodatnu -naučnoistraživačku funkciju.

\footnotetext{
${ }^{27}$ Yackley Ayla, “Turkey's Loosing Economic War", Foreign Policy, August 21, 2018.

${ }^{28}$ Ben-Meir, Alon, Xharra, Arbana, "Diyanet: Erdogan's Islamic Vehicle to the Balkans. Otoman Symbolism in Kosovo", Global Research In-depth Report professor Alon Ben-Meir Endowment, 2 June, 2018.

${ }^{29}$ Ben-Meir, Alon, Xharra, Arbana, "Turkey's Political Agenda in the Balkans. Erdogan's Islamic Influence in Bosnia", Global Research In-depth Report, September 14, 2018.

${ }^{30}$ Nikolic, Nebojsa, Jankovic, S., Vuletic, D., (2016). "Interdepartmental Cooperation in Defence Issues and Strategic Intelligence", MANAGEMENT - Journal for Theory and Practice Management, November 2016, 80, 35-44.

${ }^{31}$ Stojković, Dejan, Saković, Radiša, (2018). „Uticaj savremenih hibridnih pretnji na razvoj sistema odbrane Republike Srbije“, Tematski zbornik radova: „Hibridno ratovanje - dilema koncepta savremenih sukoba“, Institut za strategijska istraživanja, Univerzitet odbrane, Beograd, 99-109.

${ }^{32}$ Nikolic, Nebojsa, (2018), "Strengthening Defence Research as Part of Higher Military Education for Future Security Challenges", Security and Defence Quarterly, 2018, 21(4): 18-32.
} 


\section{Ruski pogled na region Jugoistočne Evrope}

Tokom januara 2019. godine objavljena je interesantna analiza o situaciji u našem širem regionu iz pera ruskih ${ }^{33}$ istraživača. Analizu odlikuje sistematičan i sažet pristup sa primetnom dozom istraživačkog objektivizma i to su osnovni razlozi da ovde bude predočena. Prema ovom ${ }^{34}$ istraživanju, ukupna regionalna situacija na Zapadnom Balkanu karakteriše se sledećim faktorima:

- Razvoj u okviru Evropske Unije (i po odrednicama usmerenim prema EU). Karakteristike prisutne na nivou EU kao što su: ekonomska neuravnoteženost; problem „centar-periferija” EU; i kriza političkih sistema negativno utiču na političke sisteme i ekonomsku dinamiku država Balkana, kao i na rast evro-skepticizma. Interni problemi naročito jačaju od početka svetske ekonomske krise 2008. godine i ogledaju se u: rastu spoljnih dugovanja, visokoj nezapolenosti, rastu cena; perifernom karakteru ekonomija; intenziviranju ekonomskih migracija. Tome treba dodati i probleme kontrole granica, prekograničnog kriminala i ilegalnih migracija.

- Infrastrukturna obnova. Faza intenzivnijeg obnavljanja infrastrukture stimulisana je kako od strane EU tako i od strane Kine (kupovina luke Pirej u Grčkoj, izgradnja autoputa Podgorica-Kolašin u Crnoj Gori), Rusije (projekti ruskih železnica u Srbiji), SAD (izgradnja autoputa na Kosovu), Turske (izgradnja autoputa Beograd-Sarajevo), UAE (projekat „Beograd na vodi“), itd. Autori ističu da ove ekonomske investicije mogu biti način za političko obavezivanje lokalnih elita prema davaocima kredita i investitorima.

- Rastući značaj Balkana kao tranzitnog regiona. Ovo važi i kada je u pitanju kineska inicijativa „Novi put svile - ekonomski pojas i put" i kada je u pitanju projekat novog gasovoda između Rusije i Turske „Turski tok“.

- Balkan postaje mesto ukrštanja interesa globalni aktera i državnog i nedržavnog karaktera. Devedesetih godina Turska je snažno implementirala svoje prisustvo i uticaj; dvehiljaditih Rusija učvršćuje svoj ekonomsko i investiciono prisustvo; a u tekućoj dekadi pojavljuje se Kina koja povećava svoj uticaj i prisustvo u regionu. Konflikt u Siriji i uspon Islamske države produbio je problem izbeglica i migranata uz koje su i militantni islamisti pronašli svoj put do Evrope preko balkanskih ruta. Pored svega, tradicionalno je snažno prisustvo kriminalnih grupa povezanih sa švercom oružja, droge i drugih zabranjenih proizvoda. Evidentan je paradoks: politička nestabilnost legalnih faktora u regionu a na drugoj strani stabilnost i fleksibilnost kriminalnih organizacija.

- Politička nestabilnost u regionu. U tekućoj dekadi, praktično sve zemlje regiona iskusile su manju ili veću političku nestabilnost (od Slovenije i Hrvatske na severozapadu, do Bugarske na jugoistoku. Problemi ove vrste u "mekom trbuhu Evrope“ bili su osnovni uzrok da Evropska Unija ne žuri sa integracijama preostalih zemalja iz regiona i da deklariše eventualnu godinu pristupanja kao: „jedino moguće posle 2025“.

Prema istraživačima ${ }^{35}$ Ruskog saveta za međunarodne odnose svojevrsna klasifikacija vodećih aktera prisutnih na Balkanu i u Jugoistočnoj Evropi, bila bi sledeća (pod na-

\footnotetext{
${ }^{33}$ Entina Ekaterina, Pivovarenko Alexander, "Russia in the Balkans", RIAC report, January 13, 2019, Russian International Affairs Council.

${ }^{34}$ Entina Ekaterina, Pivovarenko Alexander, "Russia in the Balkans", RIAC report, January 13, 2019, Russian International Affairs Council.

${ }^{35}$ Entina Ekaterina, Pivovarenko Alexander, "Russia in the Balkans", RIAC report, January 13, 2019, Russian International Affairs Council.
} 
vodnicima su termini koji su sugerisani od strane navedenih autora, pri čemu je interesantno da ovi ruski autori ne vide Rusiju kao jednog od glavnih aktera na Balkanu):

- „Plejmejkeri“ (glavni igrači-akteri), su definisani kao neko ko daje osnovni ton procesima i ima najznačajniji uticaj proporcionalno moći koju ima i primenjuje u regionu; u ovu grupu spadaju SAD, EU i Kina shodno realnoj moći koju imaju i koju mogu da projektuju u regionu. Svaka od ovih sila ima sopstvenu agendu i prioritete. Tako na primer EU želi političku stabilnost, razrešenje teritorijalnih i sličnih razmirica, ograničavanje negativnog uticaja ostalih sila, nastavak integracionih procesa ka EU ali bez tvrdih garancija, razvoj ekonomije i razvoj saobraćajne infrastrukture međunarodnog značaja. Prioriteti SAD su učvršćivanje sopstvenog ekonomskog prisustva, razvoj alternativa za obezbeđenje energenata, jačanje političkih veza i proširenje vojnog prisustva kroz uspostavljanje vojnih baza. Kina proširuje svoj politički i ekonomski uticaj u regionima gde su prisutne SAD i EU, nastoji da implementira svoj projekat poznat kao ,jedan pojas - jedan put“ što podrazumeva projekte za razvoj infrastrukture, modernizacije i investicija.

- „Krilni igrači“ (pomoćni akteri), su oni koji ispoljavaju značajan ali ne i presudan niti sistematski uticaj na region; u ovu grupu spadaju V. Britanija, Turska i Rusija, sile koje su tradicionalno kroz istoriju ispoljavale svoj uticaj u regionu. V. Britanija unapređuje sopstvene mehanizme uticaja i interakcije sa EU i NATO u pogledu prisustva u regionu, teži da ograniči utucaj Rusije i drugih spoljnih aktera i unapredi sopstveni politički i ekonomski uticaj. Turska proširuje politički uticaj i stvara sopstveni manevarski prostor za delovanje na relacijama sa drugim silama pre svega prema SAD, EU Kini i Rusiji, proširuje kulturni, verski i ekonomski uticaj i pokušava „otomanizaciju“ regiona odnosno svojevrsni povratak i uticaj na prostorima koje je vekovima okupirala, dok na drugoj strani forsira energetske projekte (gasovod od Rusije i izgradnju nuklearne elektrane sa Rusijom) i razvija transnacionalne saobraćajne kapacitete kako bi se uključila u kineski projekat ,jedan pojas jedan put“. Rusija nastoji da zadrži svoje ekonomsko prisustvo u regionu, da održi istorijski utemeljen politički i kulturni uticaj i nastoji da izbegne konfrontaciju tražeći modele nekonfliktnih relacija u odnosima sa EU i NATO.

- „Epizodni igrači“ (povremeni akteri, rezervni igrači), su oni čije uloge i zadaci su situacione prirode uz povremeno aktiviranje, kao i slabo predvidivi učesnici; u ovu grupu spadaju: Austrija i zemlje Višegradske grupe (Mađarska, Poljska, Češka i Slovačka), arapske zemlje bogate naftom (neke imaju potencijal i aspiracije da se značajnije nametnu i time pređu u višu grupu). Zemlje Višegradske grupe uključuju se u integracione procese regiona ka EU u želji da podupru sopstvene pozicije u EU računajući na sličnosti koje donekle imaju sa zemljama regiona (nivo ekonomskog razvoja, izvesna sličnost kulturnih matrica i istorijskog iskustva), da ojačaju određene centralnoevropske ekonomske i političke perspektive, kao i da povećaju nivo sopstvene bezbednosti u pogledu terorističkih pretnji i ilegalnih migracionih tokova. Pojedine arapske zemlje izvoznice nafte takođe ispoljavaju svoj uticaj u regionu, i to kroz: uspostavljanje sopstvenih trgovačkih mehanizama za prodaju nafte u Južnoj, Centralnoj i Istočnoj Evropi, povećanje ekonomskog prisustva u Evropi, učešće u transkontinentalnim, saobraćajnim, logističkim, urbanističkim, agrokulturnim projektima, proširenje kulturnog i verskog uticaja u regionu.

- „Nedržavni akteri“, pored pobrojanih državnih aktera koji na različite načine i različitim intenzitetom i dinamikom utiču na region, ne mogu se zaobići niti neki nedržavni faktori kao što su: islamisti, izbeglice sa azijskog i afričkog kontinenta, organizovane kriminalne grupe, 
i slično; ovi faktori, samostalno ili u interakciji međusobnoj ili sa državnim akterima, mogu ispoljiti veoma efektan uticaj. Uticaj različitih nedržavnih aktera ogleda se u sledećem: iskorišćavanje regionalnih transportnih pravaca za ilegalne tokove ljudi (migracije, trgovina robljem), roba (šverc), novca (pranje novca), ideja (širenje subverzivnih ideologija, verskog fanatizma, podpirivanje etničkih i rasnih sukoba); uspostavljanje mreže transnacionalnih kriminalnih mreža; uspostavljanje demografske i materijalne baze za terorističke mreže itd.

Značaj Balkana za Rusiju, prema proceni ovih ruskih istraživača ${ }^{36}$ je da bi položaj Rusije u Evropi bio značajno pogoršan u slučaju da Rusija napusti svoje interese i pozicije na Balkanu, odnosno konkretnije:

- EU zona (EU i zemlje van EU koje su kandidati ili pripadaju ovom delu evropskog prostora) bila bi ojačana uz dodatno bolje uslove za homogenizaciju i „eliminisanje ostrva" na političkoj mapi Evrope.

- Brisel bi dobio odrešene ruke za nove prilike za EU i eventualnu dalju ekspanziju na istok.

- Došlo bi do promene balansa u rusko-turskim i rusko-kineskim odnosima.

- Postojala bi mogućnost da Rusija bude isključena iz budućih transkontinentalnih saobraćajnih projekata.

- Došlo bi do diskreditacije pozitivnog razvoja (tokom 2017 i 2018. godine) u odnosima Rusije sa Bugarskom i Srbijom, dok bi se značajno zakomplikovala situacija za poboljšanje odnosa sa Grčkom i Crnom Gorom. Takođe, pozicija Srbije koja se smatra za jednog od ključnih Ruskih partnera u regionu bila bi oslabljena.

Prema mišljenju pomenutih ruskih istraživača ${ }^{37}$, predlog smernica za praktičnu politiku Rusije na Balkanu i opšta preporuka jeste da Rusija treba da kreira novu strategiju za Jugoistočnu Evropu, koja će biti jasna svim činiocima u regionu kao i zainteresovanim eksternim akterima. Takođe smatraju da nova strategija nastupa treba da bude pragmatična i jeftina u smislu da ne iziskuje velike troškove, ali da se istovremeno izbegne percepcija da je reč o reviziji odnosa sa tradicionalnim prijateljima u regionu, već pre da je reč o razumevanju sistemske pozicije istog u njegovom okruženju. Javna dostupnost ove nove strategije trebala bi da omogući njeno dobro razumevanje i povećanje ruske reputacije među državama, etničkim grupama i političkim zajednicama u multidimenzionalnom balkanskom regionu, ali i jasna platforma za diplomatske interakcije sa zemljama EU i preduslov za jasne partnerske odnose sa Kinom i Turskom koje takođe imaju sopstvene interese u Jugoistočnoj Evropi. Nova strategija Rusije za Jugoistočnu Evropu, prema pomenutom istraživanju ${ }^{38}$, treba da se zasniva na sledećim smernicama:

- Pomeranje pristupa zasnovanih na bilateralnim partnerstvima, ka pristupu zasnovanom na multilateralnoj saradnji.

- Kreiranje i podrška konstruktivnih političkih snaga u Srbiji, Sloveniji, Hrvatskoj, Albaniji i drugim zemljama u regionu koje bi bili orijentisane ka moskovskim projektima.

\footnotetext{
${ }^{36}$ Entina Ekaterina, Pivovarenko Alexander, "Russia in the Balkans", RIAC report, January 13, 2019, Russian International Affairs Council.

${ }^{37}$ Entina Ekaterina, Pivovarenko Alexander, "Russia in the Balkans", RIAC report, January 13, 2019, Russian International Affairs Council.

${ }^{38}$ Entina Ekaterina, Pivovarenko Alexander, "Russia in the Balkans", RIAC report, January 13, 2019, Russian International Affairs Council.
} 
- Ekspanzija medijskog prisustva na Balanu; zamena do sada dominantnih termina kao što su „Rusija kao provajder bezbednosti“ i „Rusija kao provajder energenata“, sa novim terminima kao što su „Rusija kao faktor regionalne stabilnosti“, „Rusija kao faktor humanitarne saradnje“ i „Rusija kao provajder modernih elektronski tehnologija i efikasnih tehnoloških rešenja".

- Nastavak ulaganja u regionalne proizvodne kapacitete (Agrokor, INA, MOL).

- Proširenje sa ekonomskog prisustva na obrazovnu, trgovinsku i kulturnu saradnju

- Razvoj konstruktivnog pristupa u tretiranju religijskih pitanja, uzimajući u obzir aktuelnu podelu u pravoslavnom svetu.

- Razvoj oblika saradnje u kojima je prisutna Rusija uz više koordinacije između različitih platformi (EAEU, OEBS, BRIKS, ...).

Navedene preporuke pomenutih ruskih istraživača koje potenciraju veću prisutnost Rusije na ovom prostoru mogu se shvatiti i kao rezultat kritičke analize postojećih ruskih strategijskih dokumenata o njihovoj spoljnoj politici. Naime, prema najnovijem dostupnom konceptu $^{39}$ ruske spoljne politike, koji koncizno navodi pored ostalih elemenata i listu prioriteta ruske spoljne politike po konkretno navedenim regionima i zemljama po celom svetu, jednostavno nema navedenog regiona u kome se nalazi Srbija.

\section{Relativni značaj Zapadnog Balkana u Turskoj agendi}

Početkom juna 2018, pojavila se jedna interesantna analiza ${ }^{40}$ odnosa u trouglu Srbija-Rusija-Turska. Konstatovano je preplitanje uticaja Evropske unije, Rusije i Turske u Srbiji, ne samo u političkom nego i u ekonomskom smislu. Istaknuta je najava turskog predsednika Erdogana da investira u Srbiju 2 milijarde dolara tokom 2018. godine, a dugoročno i do 5 milijardi dolara. Takođe se ističe Erdoganova projekcija da će Turska postati snažna i uticajna kao i Otomanska carevina na vrhuncu njene snage. Konstatuje se da se oni interesi Rusije i Turske na terenu koji su međusobno suprotstavljeni drže pod kontrolom i ne eskaliraju jer su obe zemlje procenile da im je veći problem u ovom trenutku Evropska unija. Ovaj princip „međusobnog neometanja“ odnosno kohabitacije i stavljanja po strani međusobnih problema u korist drugih većih problema koje obe zemlje percipiraju u odnosima sa Zapadom, odlika je ne samo za slučaj Srbije i balkanskih zemalja, već i u svim drugim geografskim (Kavkaz, Sirija, Centralna Azija) i drugim oblastima. U analizi je konstatovana i sličnost logike u geopolitičkom deklarisanju ciljeva Srbije i Turske: naime, i Erdogan deklariše oba geopolitička opredeljenja odnosno nameru da ostane u NATO i na putu za EU, kao i da vodi svoju politiku i razvija odnose sa kim hoće. Sumarno, uticaj Rusije i Turske na Balkanu percipira se kao realizacija sopstvenih dugoročnih strategijskih ciljeva ovih dveju zemalja pri čemu se one prikazuju kao spasioci a u suštini koriste sve osetljivosti i slabosti balkanskih zemalja.

\footnotetext{
${ }^{39}$ Ministry of Foreign Affairs of the Russian Federation, "The Foreign Policy Concept of the Russian Federation", 30, November 2016.

${ }^{40}$ Ben-Meir, Alon, "The Serbia-Turkey-Russia Axis: Alarm Bells for Europe", professor Alon Ben-Meir Endowment, 2 June, 2018. (//alonben-meir.com).
} 
Prioriteti u spoljnoj i bezbednosnoj politici Turske mogu se identifikovati i na osnovu zastupljenosti različitih tematskih sadržaja na sednicama turskog Saveta za nacionalnu bezbednost. Naravno, samo posredno, preko javno dostupnih podataka o zasedanjima ovog saveta i temama o kojima se diskutovalo na istom. Prema dostupnim podacima ${ }^{41}$, u periodu 2012-2017. godina, turski Savet za nacionalnu bezbednost sastao se oko 40 puta, a zastupljenost najvažnijih tema o kojima je raspravljano bila je sledeća:

- Sirija (36 puta diskutovana tema),

- Irak (33 puta diskutovana tema),

- Migranti (20 puta diskutovana tema),

- Libija (16 puta diskutovana tema),

- Izrael i Palestina (10 puta diskutovana tema),

- Jemen (10 puta diskutovana tema),

- Egipat (10 puta diskutovana tema),

- ISIS u Iraku i Siriji (8 puta diskutovana tema),

- Kurdska oslobodilačka vojska (8 puta diskutovana tema),

- Rusija (8 puta diskutovana tema),

- Kipar i Mediteran (8 puta diskutovana tema),

- Evropska Unija (4 puta diskutovana tema),

- Iran (4 puta diskutovana tema),

Na osnovu izloženog može se zaključiti o značaju i mestu Balkana i Srbije u sklopu ostalih bitnih spoljno-političkih i bezbednosnih pitanja u turskoj agendi. Jasno je da je region Bliskog istoka od prvorazrednog značaja u turskoj agendi, pa se u nastavku daje nešto više informacija o tome uz analizu angažmana Rusije i njenih interesa u tom regionu.

\section{Interesi Rusije i Turske na Bliskom istoku - jedan pogled iz istraživačke perspektive turskih istraživačkih resursa}

$U$ časopisu turskog centra za strategijska istraživanja nedavno je objavljena interesantna analiza ${ }^{42}$ o uticaju i interesima velikih sila na region Bliskog istoka, iz čega izdvajamo sledeće aspekte u vezi percepcije ruskih interesa na Bliskom istoku:

- Rusko interesovanje i angažovanje u regionu Bliskog istoka može se posmatrati kroz prizmu borbe protiv secesionizma na Severnom Kavkazu s obzirom na percepciju da su severnokavkaski secesionistički pokreti podržani (finansiranje i propagiranje ekstremističkih težnji i verskih radikalizama) od strane nekih zemalja iz Persijskog zaliva. U vreme borbi u Čečeniji devedesetih godina, Rusija je oštro kritikovana od strane muslimanskih zemalja, posebno onih sa Bliskog istoka. Globalni rat protiv terorizma koji je usledio (od 2001. godine) bio je prilika za Rusiju da sarađuje sa Zapadom i klasifikuje svoje vojne operacije u Čečeniji kao vid borbe protiv terorizma. Nedugo zatim (od 2003. godine) Rusija se izrazito protivila ratu protiv Iraka i tada započeta antizapadna retorika išla je u prilog poboljšanja ruskih odnosa sa musli-

${ }^{41}$ Gursoy, Yaprak, "Turkish Defence Polices and Armed Forces: Continuities and Changes since the Cold War", Proceedings ECPR General Conference 2017.

${ }^{42}$ Zulfqar Saman, "Competing Interest of Major Powers in the Middle East: The Case Study of Syria and Its Implications for Regional Stability", Perceptions, 2018, Vol. XXIII, No.1, pp.121-148. 
manskim zemljama i to u meri da je dobila i status posmatrača u organizaciji islamskih zemalja (OIC) iste 2003. godine. U prilog opravdanosti ruskog angažovanja u sirijskom sukobu idu i relativno pouzdane procene o tome da drugu najveću grupu inostranih učesnika u sirijskom sukobu na strani Islamske države i pobunjenika čine upravo pripadnici muslimanske zajednice iz Rusije. Iz ne samo ruske perspektive svakako je razumljivo da je terorističko delovanje bolje zaustaviti van granica nego dopustiti eskalaciju sukoba na sopstvenoj teritoriji, u konkretnom slučaju na Kavkazu. Uostalom, ovaj princip primenjuju i druge države koje to sebi mogu da priušte (Turska u Siriji i Iraku; SAD u Avganistanu i drugde, itd.).

- Osim bezbednosnog aspekta, postoje i drugi interesi Rusije u regionu Bliskog Istoka, a to su: ekonomski, trgovinski i politički. U ekonomskom pogledu Rusija nastoji da proširi obim trgovinske saradnje, naročito u pogledu nastupa na bogatom i zahvalnom tržištu oružja i vojne opreme. Blisko-istočno tržište naoružanja je za Rusiju drugo po značaju i vrednosti, odmah iza azijskog.

- Takođe, Rusija nastoji i u tome uspeva da se nametne i kao partner zemalja izvoznica nafte i gasa i da na taj način, zajedno sa tim zemljama, utiče na tržišne mehanizme i kontrolu cena energenata. Rusija uspeva da istovremeno održava i razvija dobre sveukupne odnose i sa zemljama u regionu koje su u nekom međusobnom sukobu - najbolji primeri za to jeste odlična saradnja Rusije sa Iranom i Saudijskom Arabijom (čiji su međusobni odnosi veoma napeti); kao i sa Sirijom i Izraelom (čiji su međusobni odnosi veoma napeti u dužem -višedecenijskom periodu).

- Pored tradicionalno dobrih odnosa sa većinom arapskih i islamskih zemalja, Rusija uspeva da održi stabilne odnose i saradnju sa Izraelom što podrazumeva i ekonomsku saradnju koja je, iskazano u novcu, veća nego sa Srbijom.

- U periodu „Arapskog proleća“ kao kriznom periodu uz seriju nestabilnosti i pobuna u mnogim zemljama u regionu u dužem periodu od početka ove decenije, Rusija je ostala neutralna što joj je dalo dobre pozicije za ostvarenje određenog političkog uticaja nakon krize (u današnje vreme) u nekim od ovih zemalja.

- Sirija je jedan od najstarijih saveznika Rusije na Bliskom Istoku (još od doba Hladnog rata) i može se očekivati da će to i ostati u doglednoj budućnosti, a naročito u završnoj fazi sukoba kao i neposredno nakon toga kada otpočne mirovni proces. Ipak, trend je da Rusija u svom angažmanu ide fleksibilno i da će biti uvaženi određeni interesi pre svega Turske i Irana u postkonfliktnom preuređenju Sirije.

$U$ istom izvoru (časopis turskog centra za strategijska istraživanja, nedavno objavljena interesantna analiza o uticaju i interesima velikih sila na region Bliskog istoka), istaknuti su i značajni aspekti u vezi percepcije turskih interesa na Bliskom istoku

- U aktuelnom trenutku, Turska politika prema Siriji kao i u regionu Bliskog Istoka ali i šire može se opisati kao „neo-otomanska real-politika“. Na početku ove decenije, turska spoljna politika mogla je biti kratko opisana kao „neo-otomanski avanturizam“, ali je tokom tekuće decenije evoluirala ka real-politici, kao posledica prilagođavanja, razmene očekivanja i trgovine uticajem i interesima sa drugim velikim silama čiji su se uticaji u regionu nametnuli kao nezaobilazan faktor. Ova fleksibilnost i prilagodljivost turske spoljne politike omogućila je Turskoj relativno uspešnu realizaciju sopstvene spoljnopolitičke agende.

- Turska je ojačala svoj uticaj u regionu, angažovala je svoju vojsku na tuđoj teritoriji a nije optužena za agresiju (Sirija, Irak). Turska je tretirana od strane Evropske Unije kao partner u bavljenju problemom nelegalnih migracija za šta je uspela da dobije i veliki novac od EU. 
- Turska je sanirala posledice (obaranje ruskog aviona na granici Turske i Sirije) u odnosima sa Rusijom za kratko vreme i na najbolji način za nju (ugovori o izgradnji nuklearne centrale sa Ruskim izvođačima, izgradnja drugog gasovoda od Rusije, nabavka naprednih protivvazduhoplovnih raketnih sistema od Rusije; ekspanzija trgovine i turizma sa Rusijom).

- Turska je uspela da balansira svoje interese i nađe način sa saradnju od strategijskog do taktičkog nivoa na terenu sa Rusijom i Iranom u sukobu u Siriji.

- Takođe, Turska vešto balansira u odnosima sa SAD maksimalno koristeći svaku priliku za približavanje i učvršćivanje svoje pozicije (slučaj ubistva američkog novinara saudijskog porekla u Turskoj; slanje visokih delegacija u Vašington kad god dođe do razmimoilaženje sa SAD; neprekidanje ekonomskih, vojnih, obrazovnih i drugih oblika saradnje sa SAD), ali i zatezanjem odnosa do krajnjih granica pre svega kada je to važno za unutrašnju političku upotrebu (masovna hapšenja, otpuštanja i kažnjavanja osumnjičenih lica za državni udar, traženje spoljnih krivaca ${ }^{43}$ za slabost nacionalne valute i inflaciju, itd.).

Turska nastoji da razvije i održi dobre i srdačne odnose sa praktično svim zemljama i u regionu Balkana. Uočljiva je deklarativna „intenzivna pozitivnost“ i u odnosima sa Srbijom, ali pri tome Turska ni za milimetar ne odstupa od svojih još boljih odnosa sa zemljama koje okružuju Srbiju a prema kojima se ona postavlja kao mentor, sponzor ili promoter, uostalom Turska je među prvima priznala tzv. Kosovo, a više puta ranije su i Kosovo i BiH proglašavali svojim. Izvesni nesporazumi turskog državnog vrha sa delom privremenih vlastodržaca na tzv. Kosovu koji su se pojavili tokom prethodne godine, nisu nikako revizija turske politike prema kosovskom pitanju a još manje ustupak ili usluga Srbiji, već isključivo produkt unutrašnje-političkih razmirica u Turskoj (deo kosovskih političara iz vlasti napravili su određene poteze u prilog pokreta gulenista koji su u Turskoj percipirani kao neprijatelji, a kako ih podržavaju SAD, još se smatraju i izdajnicima).

Osnovni i primarni motiv turskog angažovanja u Sirijskom sukobu jeste borba protiv Kurda. Može se čak reći da je sukob u Siriji savršeno opravdanje Turskoj da potiskivanjem Kurda (sirijskih Kurda) razreši sopstveni unutrašnji višedecenijski politički i bezbedonosni problem koji ima sa kurdskom manjinom na istoku i jugoistoku zemlje.

\section{Osvrt na međusobne odnose Rusije i Turske}

\section{Odnosi Turske i Rusije iz Ruske perspektive}

Početkom avgusta 2018, pojavila se analiza odnosa Turske i Rusije iz ugla jedne ugledne ruske akademske institucije (Ruski savet za međunarodne odnose) čiji su osnivači pored ostalih i: rusko ministarstvo spoljnih poslova, ministarstvo obrazovanja i nauke i ruska akademija nauka, što daje poseban značaj ovom institutu. Osnovna poruka jeste da odnosi Rusije i Turske treba da budu dublji i jači, pored nastavka obostrano pragmatičnog pristupa i međusobno tolerantnog uvažavanja. U analizi ${ }^{44}$ se ističe sledeće:

- međusobni odnosi Rusije i Turske su važni za obe strane;

\footnotetext{
${ }^{43}$ Yackley Ayla, “Turkey's Loosing Economic War”, Foreign Policy, August 21, 2018.

${ }^{44}$ Kortunov, Andrey, "Russia-Turkey Relations Need a Stronger Foundation", report, Russian International Affairs Council, RIAC, August 2, 2008.
} 
- postoji svest da će uvek biti mešavine zajedničkih, paralelnih, preklapajućih ali i suprotstavljenih interesa;

- jasno je da će treće strane (drugi globalni i regionalni akteri) nastaviti da ostvare uticaj na međusobne odnose Rusije i Turske;

- obe zemlje treba da se zalažu za stabilnije i predvidljivije međusobne odnose sa manje suprotstavljenosti i negativnih konotacija;

- u cilju održavanja i razvijanja odnosa, neophodno je uspostaviti, održavati i razvijati brojne linije komunikacije;

- razviti mehanizme za razrešavanje neslaganja: ne ići na zaustavljanje odnosa, već suprotno, tražiti inovativne načine za razrešavanje („da deo problema, postane deo rešenja“).

\section{Odnosi Rusije i Turske iz Turske perspektive}

Početkom jula 2018, pojavila se analiza sličnih karakteristika Turske i Rusije iz ugla jedne ugledne turske akademske institucije (Ankara centar za krizne i političke studije), koja u najkraćem sugeriše sledeće trojstvo: „jako rukovodstvo - jak sistem - jaka drža$v^{45 ، .}$. Sveukupni razvoj i osnaživanje Rusije naročito tokom poslednje decenije viđen je kroz prizmu jakog lidera koji je zemlju koja je bila blizu ,jugoslavizacije“ uspeo da izvede iz krize ponovo vrati na svetsku scenu u punom sjaju, uz emancipaciju tradicionalnih vrednosti, jačanje nacionalnog identiteta i poštovanje istorije. $U$ tom smislu vidljiva je sugestivna paralela o aktuelnim sličnostima Rusije i Turske i putu kojim Turska treba da nastavi da ide. Interesantna je upotreba termina ,jugoslavizacija ${ }^{46 “}$ umesto poznatijeg termina „balkanizacija“. Istina, termin „jugoslavizacija“ jeste korišćen početkom devedesetih godina u Rusiji, sa početnom namerom da se imenuje pojava kada pojedina federalna jedinica želi da napusti federaciju, ali značenje i dalja upotreba ovog termina ipak transformisano u smislu neizbežnosti građanskog rata ako se ignorišu pojedinačne nacionalne aspiracije. Preferiranje termina „jugoslavizacija“ nad „balkanizacijom“ može značiti i pokušaj relaksacije negativne konotacije ovog drugog termina i svaljivanje negativnih pojava iz balkanskog konteksta na jugoslovenski kontekst.

Početkom avgusta 2018. pojavilo se novo kritičko gledište iz iste institucije (Ankara centar za krizne i političke studije), sa osvrtom na potencijale za krizu ${ }^{47}$ u tursko-ruskim odnosima, pri čemu su date moguće sporne teme u neposrednoj budućnosti prema sledećem:

- Podela zona uticaja u „Novoj Siriji“;

- Želja Moskve da uspostavi zonu uticaja u regionu severne Sirije, što može ugroziti bezbednost Turske i dovesti do mnogih neželjenih problema;

- Naklonost Moskve Asadu i tolerancija Iranskog uticaja u Siriji;

- Iranska kriza i pozicija Turske u vezi iranske krize.

\footnotetext{
${ }^{45}$ Seyfettin, Mehmet, Erol, "Fundamental Dynamics and Russia Dimension of the New Turkish Foreign Policy Direction", report, Ankara Center for Crisis and Policy Studies, ANKASAM, 6 Jul, 2018.

${ }^{46}$ Sneider, Daniel, "The world from...Moscow", The Christian Science Monitor, November 26, 1991.

${ }^{47}$ Seyfettin, Mehmet, Erol, "Potential Crisis in Turkish-Russian Relations", report, Ankara Center for Crisis and Policy Studies, ANKASAM, 4 August, 2018.
} 
- Takođe, tu je i pitanje daljeg razvoja odnosa Turske i SAD ${ }^{48}$, aktuelna konfuzija i neodređenost ${ }^{49}$, pozicija Turske u NATO ${ }^{50}$, kao i pitanje razvoja poverenja i pouzdanosti istog sa svim dosadašnjim zapadnim partnerima ${ }^{51}$.

Obe zemlje intenzivno sarađuju na rešavanju krize i koordinaciji međusobnih aktivnosti u Siriji, kroz posebnu formu saradnje poznatu kao „Astana format“, u sklopu koga održavaju periodične sastanke zajedno sa drugim stranama. Delovanje u ovom forumu deklarišu kroz sledeće aspekte: reafirmacija posvećenosti suverenitetu, nezavisnosti i teritorijalnom integritetu Sirije; de-eskalacija sukoba u provinciji Idlib i drugim mestima; reafirmisana odlučnost borbe protiv terorizma koji provodi DAES/ISIL, Nusra Front i druge grupe u vezi sa Al-kaidom; ohrabrivanje povratka izbeglica i stvaranja uslova za normalizaciju života; itd.

\section{Zaključak}

Suprotstavljeni akteri na Zapadnom Balkanu u dužem istorijskom periodu često su bili u funkciji ostvarenja interesa velikih sila iz čega su proistekli i određeni stereotipi u pogledu podrške koje pojedine velike sile tradicionalno daju pojedinim akterima na ovom prostoru. Međutim, velike sile imaju sopstvene agende i prioritete. One se međusobno sučeljavaju i u nizu drugih regiona, drugih oblasti i pitanja. Uočljiv je veliki pragmatizam u međusobnim odnosima velikih sila i svojevrsna razmena usluga i uticaja, međusobnu toleranciju interesa i ne-eskalaciju sukoba. Gotova svaka aktivnost jedne sile u jednom regionu uzrokuje potrebu za određenom protivuslugom u nekom drugom regionu ili nekom aspektu međusobnih odnosa. U tom smislu, očekivanja malih zemalja na Zapadnom Balkanu često su veća i nerealna jer su usko fokusirana samo na sopstveni problem.

Može se očekivati nastavak dosadašnjih pragmatičnih trendova u spoljnoj politici Turske i Rusije i njihova dalja prisutnost i aktivnosti na Balkanu i u Srbiji, kao u ostalom i na drugim geopolitičkim mestima u skladu sa njihovom spoljnom politikom i povećanu međusobnu pažnju i poštovanje međusobnih interesa uz uzdržavanje od bilo kakvih međusobnih sukoba u incidentnim situacijama na bilo kojoj geopolitičkoj tački. Pri tome, Balkan i Srbija nisu visoko na listi prioriteta u ruskoj i turskoj strategijskoj agendi.

Rusija i Turska su i dalje pod rastućim pritiskom i opservacijama sa Zapada na više polja (vojno, ekonomsko, političko,...), a najnoviji slučajevi su: zaoštravanje stavova u vezi krize u Venecueli (gde su Rusija i Turska na istoj strani), kao i zaoštravanje odnosa sa SAD i EU u vezi napuštanja sporazuma o likvidaciji raketa srednjeg i kratkog dometa iz osamdesetih godina prošlog veka. Ovaj raketni problem tiče se i EU pa ostaje da se vidi na koji način će ona reagovati, posebno zato što je reč o teritoriji zemalja EU, a SAD i

\footnotetext{
${ }^{48}$ Saidel, Nicolas, Finkelstein, Claire, "Turkey's Eastern Pivot: A Challenge for NATO and a Threat to US National Security", report, Center for Ethics and the Rule of Law, University of Pennsylvania, January 19, 2018.

${ }^{49}$ Tzogopoulos, George, "Debate: What's Next for Turkey?", report, The Begin-Sadat Center for Strategic Studies, BESA, July 13, 2018

${ }^{50}$ Bay Austin, "Erdogan's Turkey and NATO", Strategika, Issue 52, July 31, 2018, Hoover Institution.

${ }^{51}$ Kirisci Kemal, Toygur Ilke, "Turkey's New Presidental System and a Changing West: Implications for Turkish Foreign Policy and Turkey-West Relations", Policy paper No. 15., Foreign Policy at Brookings Institute, Washington, D.C.
} 
Rusija slede sopstvene interese u kom smislu je i dalje uočljiv međusobni pragmatizam u odnosima pre svega na bilateralnom nivou SAD-Rusija. U neposrednoj budućnosti treba očekivati konkretnije reakcije EU na pomake u izgradnji gasovoda "Turski tok“ i najave spremnosti zemalja regiona da se na isti priključe. U prilog tome je i problematiziranje izgradnje gasovoda "Severni tok“.

\section{Literatura}

[1] Alexandrova-Arbatova, Nadia, "The Russia-Turkey Relations: Startegic Partnership or Strategic Rivalry", Policy paper series 4/2018, December 2018, Cyprus Center for European and International Affairs, University of Nicosia, Cyprus.

[2] Bay Austin, "Erdogan's Turkey and NATO", Strategika, Issue 52, July 31, 2018, Hoover Institution, www.hoover.org

[3] Ben-Meir, Alon, "The Serbia-Turkey-Russia Axis: Alarm Bells for Europe", professor Alon Ben-Meir Endowment, 2 June, 2018. (//alonben-meir.com).

[4] Ben-Meir, Alon, Xharra, Arbana, "Diyanet: Erdogan's Islamic Vehicle to the Balkans. Otoman Symbolism in Kosovo", Global Research In-depth Report professor Alon Ben-Meir Endowment, 2 June, 2018. (www.theglobalist.com).

[5] Ben-Meir, Alon, Xharra, Arbana, "Turkey's Political Agenda in the Balkans. Erdogan's Islamic Influence in Bosnia", Global Research In-depth Report, September 14, 2018. (www.globalresearch.ca).

[6] Берић, Ненад, Јовић, Никола, Симић Ненад, (2018). „Улога специјалних снага у хибридном ратовању“, Тематски зборник радова: „Хибридно ратовање - дилема концепта савремених сукоба“, Институт за стратегијска истраживања, Универзитет одбране, Београд, 132-150. http://www.isi.mod.gov.rs/

multimedia/dodaci/hibridno_ratovanje_tematski_zbornik_isi_2018_1545986523.pdf

[7] Цветковић, Ненад, Ковач, Митар, Мак, Антонио, (2018). „Економски садржај хибридног ратовања“, Тематски зборник радова: „Хибридно ратовање - дилема концепта савремених сукоба“, Институт за стратегијска истраживања, Универзитет одбране, Београд, 151-168.

[8] Čeperković Marko, Gaub Florence, "Balkan Futures", Chaillot Papers, August 2018, European Union Institute for Security Studies, 2018. (www.iss.europa.eu )

[9] Entina Ekaterina, Pivovarenko Alexander, "Russia in the Balkans", RIAC report, January 13, 2019., Russian International Affairs Council (RIAC, //russiancouncil.ru)

[10] Graham Thomas, Levitsky Jonathan, Munter Cameron, Wisner Frank, "Time for Action in the Western Balkans", Policy report, May 2018, EastWest Institute, (www.eastwest.ngo )

[11] Gursoy, Yaprak, "Turkish Defence Polices and Armed Forces: Continuities and Changes since the Cold War", Proceedings ECPR General Conference 2017 (the paper will be published in a book for 2018)

[12] Hartwell, Chritopher, "Saradnja Srbije sa Kinom, Evropskom unijom, Rusijom i Sjedinjenim Americkim Drzavama", Studija Resornog odeljenja Glavne uprave za spoljnu politiku Evropski parlament, EU, 2017.

[13] Kirisci Kemal, Toygur llke, "Turkey's New Presidental System and a Changing West: Implications for Turkish Foreign Policy and Turkey-West Relations", Policy paper No. 15., Turkish project, Foreign Policy at Brookings, Brookings Institute, Washington, D.C., January 2019.

[14] Kortunov Andrey, Ersen Emre, "Deepening Turkey-Russia Relations", Perceptions, 2018, Vol. XXIII, No.2, pp.1-3. 
[15] Kortunov, Andrey, "Russia-Turkey Relations Need a Stronger Foundation", report, Russian International Affairs Council, RIAC, August 2, 2008 (//russiancouncil.ru )

[16] Lisovolik Y.D., Chimiris E.S., "Serbia - EAEU: Integration Prospects in a Free Trade Area", RIAC working paper, 37/2018, Russian International Affairs Council (RIAC, //russiancouncil.ru)

[17] Миленковић Милош, Насилна промена режима као садржај хибридног рата, Војно дело 6/2017.

[18] Milošević Davor, Pojmovno određenje fenomena „hibridnog ratovanja“, Vojno delo 3/2018.

[19] Миљковић, Милан, (2018). „Хибридно ратовање у савременим доменима. Пример информационих операција“, Тематски зборник радова: „Хибридно ратовање - дилема концепта савремених сукоба“, Институт за стратегијска истраживања, Универзитет одбране, Београд, 169-180.

[20] Ministry of Foreign Affairs of the Russian Federation, "The Foreign Policy Concept of the Russian Federation”, 30, November 2016, (www.rusemb.org.uk/rp_insight)

[21] Митровић Мирослав, Јавна дипломатија у парадигми хибридног концепта сукоба, Војно дело 2/2018.

[22] Митровић Мирослав, Економски и енергетски аспекти хибридног угрожавања националне безбедности, Војно дело, Београд, 6/2017.

[23] Mitrović Miroslav, Genesis of Propaganda as a Strategic Means of Hybrid Warfare Concept, Vojno delo, International Edition, 1/2018.

[24] Nikolic, Nebojša, Janković, S., Vuletić, D., (2016). "Interdepartmental Cooperation in Defence Issues and Strategic Intelligence", MANAGEMENT - Journal for Theory and Practice Management, November 2016, 80, 35-44.

[25] Nikolić, Nebojša, (2017). "Comparative Review of Hybrid Warfare and Special Warfare", Thematic Conference Proceedings of International Scientific Conference "Archibald Reiss Days 2017", Academy of Criminalistic and Police Studies, 7-9 November 2017, Belgrade, Serbia, Volume 1, pp. 253-262.

[26] Николић Небојша, (2017), “Разматрање иновативности концепта хибридног ратовања", часопис Војно дело, број 5, 2017, 320-332.

[27] Nikolić Nebojča, (2018), "Connecting Conflict Concepts: Hybrid Warfare and Warden's Rings", Information \& Security: AnInternational Journal Vol.41: 21-34.

[28] Nikolic Nebojsa, (2018), "Obstacles in Inter-Organizational Cooperation and Hybrid Threats", Information \& Security: An International Journal Vol.39: 29-41.

[29] Nikolić, Nebojša, (2018), "Strengthening Defence Research as Part of Higher Military Education for Future Security Challenges", Security and Defence Quarterly, 2018, 21(4): 18-32. http://securityanddefence.pl/resources/html/article /details?id=179702

[30] Саковић Радиша, Мирослав Р. Терзић, Употреба друштвених мрежа у хибридном ратовању, Војно дело 7/2018.

[31] Saidel, Nicolas, Finkelstein, Claire, "Turkey's Eastern Pivot: A Challenge for NATO and a Threat to US National Security", report, Center for Ethics and the Rule of Law, University of Pennsylvania, January 19, 2018.

[32] Seyfettin, Mehmet, Erol, "Fundamental Dynamics and Russia Dimension of the New Turkish Foreign Policy Direction", report, Ankara Center for Crisis and Policy Studies, ANKASAM, 6 Jul, 2018 (//ankasam.org).

[33] Seyfettin, Mehmet, Erol, "Potential Crisis in Turkish-Russian Relations", report, Ankara Center for Crisis and Policy Studies, ANKASAM, 4 August, 2018 (//ankasam.org).

[34] Sneider, Daniel, “The world from...Moscow”, The Christian Science Monitor, November 26, 1991. 
[35] Стојковић, Дејан, Саковић, Радиша, (2018). „Утицај савремених хибридних претњи на развој система одбране Републике Србије“, Тематски зборник радова: „Хибридно ратовање - дилема концепта савремених сукоба“, Институт за стратегијска истраживања, Универзитет одбране, Београд, 99-109.

[36] Subotić Milovan, Miroslav Mitrović: „Hybrid Nature of Extremism: Cohesive Characteristics of Ethno-Nacionalism and Religious Extremism as Generators of Balkan Unsecurity“, Vojno delo, International Edition, 1/2018.

[37] Tagarev, Todor, (2018). "Hybrid Warfare: Emerging Research Topics", Information \& Security: An International Journal Vol.39, 289-300.

[38] Tzogopoulos, George, "Debate: What's Next for Turkey?", report, The Begin-Sadat Center for Strategic Studies, BESA, July 13, 2018 (//besacenter.org )

[39] Vračar Milinko, Milica Ćurčić, „The Evolution of European Perception of the Term Hybrid Warfare", Vojno delo, 1/2018.

[40] Vučinić Dejan, Psihološko ratovanje u prostoru društvenih informacionih medija - aspekt hibridnog ratovanja, Vojno delo, 7/2017.

[41] Васиљевић, Драган, Васиљевић, Јулијана, Ђурић, Алаксандар, (2018). „Сајбер простор - Дефиниција и класификација“, Тематски зборник радова: „Хибридно ратовање - дилема концепта савремених сукоба“, Институт за стратегијска истраживања, Универзитет одбране, Београд, 214-227.

[42] Вујчић, Игор, (2018). „Допринос културне антропологије идентификацији, превенцији и разумевању хибридних претњи у друштвеној и информационој сфрери“, Тематски зборник радова: „Хибридно ратовање - дилема концепта савремених сукоба“, Институт за стратегијска истраживања, Универзитет одбране, Београд, 183-194.

[43] Yackley Ayla, "Turkey's Loosing Economic War", Foreign Policy, August 21, 2018. www.foreignpolicy.com

[44] Zulfqar Saman, "Competing Interest of Major Powers in the Middle East: The Case Study of Syria and Its Implications for Regional Stability", Perceptions, 2018, Vol. XXIII, No.1, pp.121-148. 